\title{
Building An Employment Market without Confrontational Trade Unions: A Pattern of Core Employment Expansion in Korea and China
}

\author{
Cheng Wang*
}

\begin{abstract}
A core employment market based on modern information and communications technology (ICT) and human resources (HR) management can fundamentally overcome the shortcomings of a traditional employment market, in which the problems of an imbalance in the relationship between employers and employees are antagonistically alleviated by independent trade unions and other similar means. Core employment means the portion of total employment closely related to modern entrepreneurial innovation - the employment of directly or indirectly aiding in conducting, promoting, protecting and expanding innovation with entrepreneurship. The severe industrial conflicts existing currently in Korea and China can probably be resolved by economic and social measures other than confrontational trade unions, as long as the efforts are made in an expansion of core employment by the government, enterprises and individuals.
\end{abstract}

Keywords: Core Employment, Trade Union, Innovation, China-Korea Relations.

\section{INTRODUCTION}

China and Korea share a few common national attributes. They have both been affected strongly by Confucianism throughout their histories and they both have a strong emphasis on the responsibilities of the government to its society and the cooperation between employers and employees. Nevertheless the Korean economy has developed much more rapidly than China's economy: the per capita GDP is more than US $\$ 11,000$ in Korea, while in China it is as yet only US $\$ 1,000$. The same situation is true in industrialization, urbanization and other aspects of social modernization. In all these ways, China stands to learn a great deal from Korea.

However, several serious problems are faced by both China and Korea, such as: how to select a suitable strategy and relevant tactics for developing a national division of labor in the modern world economy, how to create and maintain the competence of entrepreneurial innovation in the economy, and how to develop core employment and correctly deal with the relationship between this issue and the trade unions (Wang, 2002). This paper will try to analyze the conflict in employment between employers and employees, and raise new suggestions to form an appealing, compatible arrangement for the promotion of core employment and virtuous interaction among employers, employees and governments in a modern market economy.

\section{ROLES OF TRADE UNIONS IN TRADITIONAL MARKETS AND CORE EMPLOYMENT MARKETS}

In modern labor economics, a trade union is an important element in altering free competition and acts as a force of monopsony in the labor market. Trade unions shift the equilibrium and, other things being

Professor of Economics, Director of the Macroeconomics Department, Institute of Economics, Chinese Academy of Social Sciences. 2 Yuetan Beixiaojie, Beijing 100836, P.R. China. E-mail: wangcheng@cass.org.cn 
equal, create more unemployment and higher labor costs for firms.

A traditional employment or labor market refers to a labor market in the early stages of market economy development. This stage has the properties of the transition from an agricultural society to an industrial society, has a less developed capital market, sees only slow advances in science and technology, has a very limited social education, a relatively long-term cycle for firm innovation, and a low rate of transmitting media information. A gap is bound to appear between the supply-side and demand-side in the traditional labor market. This gap can be found in several aspects, such as conflicts in: property rights, knowledge, communication, social status and unbalanced legislation constraints.

Therefore theories of the working class have been produced by labor supply-side theorists - such as 'reasonable rebellion' and 'reasonable confrontation' - in industrial relations. On the extreme side of these theories, violent revolution was suggested. On the conservative side, theories of active trade unions were introduced. Although the trade-union theory insisted on obtaining the reasonable economic interest of employees instead of that of the state political power, most of these theoretical viewpoints suggested the use of confrontational means such as striking, production halts, collective demonstrations and pickets. ${ }^{\prime}$ Hence, an independent trade union, from its birth, meant a confrontational organization. The likely positive effects of a union on an economy include correcting the neglect of employee interests, assuring the continuation of the productive process, and a limiting of any possible violent conflicts among individuals or society at large. Negative effects of unions include the limitation of social selection, the discouragement of entrepreneurial innovation, higher incurred labor costs, halts in production due to strikes, and the undoing of a firm's international competitiveness.

A core employment market refers to a new relationship between an employer and employees, which comes from modern entrepreneurial innovation, adoption of information and communications technology (ICT), and human resources (HR) management in the labor market. Core employment means that portion of total employment closely related to modern entrepreneurial innovation - the employment of directly or indirectly aiding in conducting, promoting, protecting and expanding innovation with entrepreneurship. Innovation includes the introduction of new technology, the finding of new sources of raw materials, new adjustment of business organization, the manufacture of new products, and the expansion of new markets (Schumpeter, 1912).

A few characteristics of a core employment market can be found if we compare it to a traditional employment market. Firstly, the development of modern divisions of labor has brought about detailed and concrete standards of labor type, grade, position, working-condition, and compensation level. Most employment can run on the basis of these standards rather than on the previous, subjective judgments of a boss. Second, along with the social modernization of the rule-of-law, the government settles problems or conflicts in labor relations to a much greater extent based on the laws, and in a fairer and more independent manner. Third, enterprises generally shift their focus from being only on the interest of stockholders to that of the stakeholders, as long as the modernization of managerial ideology and the firm's responsibility of serving the community are concerned. This practice has greatly reduced conflicts among different owners of production factors. Fourth, in the development of human resources management, the employer cares not merely for the contribution of each employee to the firm's profitability, but also for the design of the employee's career, under the help of the firm. In this way, most of those who were previously "bosses" have changed into the "coaches" of a production team in modern enterprise. Fifth, the gap of knowledge between managers and lower-tiered employees has greatly narrowed resulting from the rise in living conditions, the spread of middle and higher education and the concept of democracy in modern society. This factor weakens discrimination and conflicts

I A special group of strikers organized to keep the order and prevent non-striking co-workers from work during the striking period. 
between those in the same enterprise situation. Sixth, by usage of ICT technology and the influence of information exposition, every level of employee can get access to necessary firm messages and can more easily contact top management. Therefore, potential contradictions in management can usually be resolved at the beginning rather than becoming more severe over time.

Therefore the scale and place of industrial conflicts are quite different for traditional and core employment markets. Independent trade unions would play less and less of a role in a core employment market since most of the functions of these unions would be replaced by the means of modern management. As we have seen in most of the developed and developing countries, where and when the traditional employment style was prevalent, independent trade unions boomed, whereas where and when the core employment style prevailed, the independent trade unions declined.

\section{REQUEST AND THE CAUSES OF INDEPENDENT TRADE UNIONS IN CHINA}

The Chinese labor market emerged only after reform and a policy of openness came about in 1978. The transition of employment from a planned arrangement to marketized employment was undergone in three main stages - a rural economic reform mainly in the early period of the 1980s, a state owned enterprises (SOE) reform mainly in the early period of the 1990s and the integration of internal and international 'marketization', as well as the all-China urban-rural employment promotion policies during the initial years of the new millennium.

There are three labor pools that embody labor supply in China's current labor market. Firstly, there is the newly-built labor force in urban areas, on the scale of 12 million annually, among which is an estimated 3 million college graduates from the past three years. Second, there is the re-entry labor force of some 12 million in urban areas, coming from laid-off and unemployed workers, among whom are 6 8 million registered laid-off employees. Since 1994, laid-off employees have been assisted by government projects, notably the "re-employment project" and the "40-50 project", which mirror employment schemes in western market economies. Finally, the third pool of labor comes from redundant labor in rural areas, which comprises 120 150 million people.

The demand for labor in the Chinese labor market stems from 'marketized' enterprises, including reformed state-owned enterprises (SOEs), share-holding companies, limited liability companies and jointly-owned, collectively-owned, privately-owned, individually-owned, and foreign-funded enterprises, excluding the labor demands of the government sector and the administrative sector, such as public utilities, infrastructure and military industries. Thus, most of the labor demand is derived from the market labor force, which is subject to market competition.

In contrast to the 'marketization' of labor supply and demand in the Chinese economy, the system of trade unions in China has largely retained the old features of a traditional planned economy. The leader of China's trade unions is a member the Communist Party of China's (CPC) top committee. Local trade unions act under the leadership of local CPC organizations. Firm trade unions act under the leadership of the CPC branch if there is a branch in the firm. Facing the close relationship between the governments and CPC organizations at each level, the activities of trade unions have to retain consistency with the orientation of government policies. In 2002 there were 130 million trade union members in China, which was 52 per cent of the total number of urban employees ( 247 million). Almost all employees in the government sector, SOEs and collective-owned firms, have entered the official trade unions. In non-public or privately-owned enterprises, only 73 per cent of the employees are union members, most of whom work in domestic private enterprise; the remainder being employed by foreignfunded enterprises. However, most of the trade-union leaders in private enterprise are either related to the company head or are themselves in positions of power within the company. Therefore, laid-off, unskilled workers in traditional employment markets or enterprises come from rural areas where they have been 
farmers or casual workers, who have experienced poor status, wages and other labor conditions and find it very difficult to get assistance from the local government. These workers have a strong motivation to build an independent trade union to protect their own interests.

In August 2001 a "Trilateral Meeting" mechanism was established with the help of the International Labor Organization (ILO) in order to reduce the imbalance of strength among employees, employers and governing bodies in China's labor market. One party involved in this meeting was the Ministry of Labor and Social Security, acting as the government representative, another was the AllChina Federation of Trade Unions, as workers representative, and the third party was the Enterprise Association of China and Chinese Entrepreneurial Society, as the employers representative. This meeting has been held annually on a grand scale, and quarterly on a small scale at both national and provincial levels.

This meeting has helped to solve or alleviate some problems in areas such as labor contracts, labor conflicts with SOE reforms, compensational contractions, work conditions, quarrels between employers and employees and trade unions. However, the Trilateral Meeting still faces many tough tasks in fields such as the protection of union leaders from revenge or the mistreatment of employers, the prevention of nepotism between the employer and the union leaders, or making the enterprise association independent of governmental intervention. Other tasks include: correcting the trilateral asymmetry of information and power; noticing the special interest of new professions or special skills; reducing the shock between unions led by the CPC and the market bargainers; reinforcing the weaker side in wage bargaining in the labor market; making up the legislative shortages; and complementing details for employees on strikes and engaged on picket lines. ${ }^{2}$

\section{SPECIAL BACKGROUND FOR THE INDEPENDENT TRADE UNIONS IN KOREA}

Since its foundation in 1948, after thirty-five years under Japanese colonization and three years of American-aided governance, South Korea has experienced more than three decades of a nationally unified trade union, which was established by the government in the labor market in order to maintain unified action against North Korea and the perceived threat of "communism". The situation of trade unions in South Korea, therefore, was very similar to that of China in the way that the activities of the union kept consistency with the government. Meanwhile the South Korean government practiced a policy of "Growth First", making every effort to help and support Korean employers but ignoring any unreasonable and even unlawful infringement upon the rights of the employees.

Korean workers fought for their rights against the employers on a large scale mainly in the 1980s and 1990s (see Table 1).

\footnotetext{
2 A special zone set up by strikers in order to prevent non-striking co-workers from working during the striking period.
} 
Table 1. Trade Union Activities in South Korea

\begin{tabular}{l|r|r|r|r|r|r|r}
\hline Period & $\mathbf{1 9 6 5 - 6 9}$ & $\mathbf{1 9 7 0 - 7 4}$ & $\mathbf{1 9 7 5 - 7 9}$ & $\mathbf{1 9 8 0 - 8 4}$ & $\mathbf{1 9 8 5 - 8 9}$ & $\mathbf{1 9 9 0 - 8 4}$ & $\mathbf{1 9 9 5 - 9 8}$ \\
\hline \hline $\begin{array}{l}\text { Labor } \\
\text { Conflicts }\end{array}$ & 589 & $199 *$ & 546 & 892 & 7719 & 1056 & 379 \\
\hline $\begin{array}{l}\text { Union } \\
\text { Members } \\
(10 K)\end{array}$ & 186.5 & 268.9 & 469.4 & 492.0 & 694.6 & 875.1 & 610.0 \\
\hline $\begin{array}{l}\text { Membership } \\
\text { Rate } \\
\text { (Members/ }\end{array}$ & 22.0 & 20.5 & 23.6 & 18.7 & 18.8 & 18.6 & 14.3 \\
$\begin{array}{l}\text { Formal } \\
\text { Employees) }\end{array}$ & & & & & & \\
\hline
\end{tabular}

Note: * Includes only figures for 1970 and 1971.

Source: Koo, 2004 (198-200); the figures were also counted by th author.

Quite a few researchers have given reasons to explain why there were no independent trade unions and few labor riots during 1960s and 1970s in South Korea. The first reason they mentioned was the political reason. On one hand, South Korea was used to a national militarized administration. Since all young men must serve in the army and the country was for a long time ruled by a military government, the society and enterprises were managed, to a large extent, on a military model. Hence, employees had to obey - and got used to obeying - the orders of the firm's managers. On the other hand, the country was in the habit of being highly cautious about any seemingly "communist" ideology, and regarded independent trade unions as an outcome of "communism". The government, therefore, engaged in the practice of forbidding any independent unions.

The second reason that is put forth is the cultural reason of Confucianism. Koreans believe in the concept that different and unequal levels of people in a society are natural and reasonable. People in an upper level always looked down on the ones below them. People at the lower levels did not usually respect themselves and always attempted to climb out of their situation without taking action against the unfair treatment from above. Also, they believed in the authority of the patriarch of a family and were always ready to accept his decisions without asking whether the decisions were reasonable or not.

The third reason lay in the economy. The income gap between Koreans was not greatly enlarged during the process of industrialization; therefore, most people with a low income could tolerate their living conditions without too much complaint about their poverty. The government adopted many policies to decrease the income gap, such as control of the wage differences, assistance to rural development, improving, to some extent, working conditions and, in general, keeping governmental officials hard-working and clean.

Why, then, did independent or confrontational trade unions arise later in South Korea? It is in my opinion - shared with several other authors - that the causes lay in both the economic aspect of the employment market and the non-economic aspects of society.

In the Korean labor market, the demand for labor began to outstrip the labor supply in some areas, such as skilled industrial workers, in the mid-1970s, due to the fact that the "unlimited" supply of rural labor had been gradually absorbed by Korea's rapid industrialization (Bai, 1982). However, a real shortage of skilled workers did not arise in the labor market until the mid-1980s, when a real turning point took place in South Korean labor supply and demand (Koo, 2004). This turning point meant that the workers started gaining bargaining power against employers and were even able to claim the right to 
set up independent trade unions. This was the cause of the large-scale labor conflicts that occurred during the late 1970s.

Another, more important, reason for labor conflict resulted from the mistreatment of the labor interests by the employers. Firstly, most Korean employers regarded themselves as being the patriarch of the "enterprise family" and wanted their employees to work harder and for a longer time (up to 12 hours a day, seven days a week), but they did not take on the responsibilities of a patriarch such as taking care of employees' health and technical training. Second, the employer generally mistreated employees. An employer could not only exhaust the body and health of his employees, but also was in a position to abuse employees in spirit and personal dignity. In some cases an employer might even hit or sexually harass his employees. Because of this, a growing rancor against abusive employers developed among workers and they looked for any chance to express this bitterness, or "han" (Koo, 2004,170). Third, workers could not usually improve their lives at the rate of the economic or productive growth. They had to face alone the miserable situations of illness, work injury, or even disability, due to either overwork or poor work conditions.

Apart from these economic causes, other factors also influenced the development of independent trade unions in South Korea. These include, first of all, that most of the society could no longer tolerate the rule of dictatorship; in October 1979, President Park Chung Hee was killed by one of his officials. The government had to relax its tight control over social ideology and activities. The Korean government changed its "growth first" policy into an "economic stability and equity" focused policy in 1980. From 1982, the government even cancelled the 37-year long curfew. Second, Christianity had spread rapidly from America to South Korea and provided good opportunities for the open exchange of employees' grievances and for the organized collective protests of workers, without being called illegal. ${ }^{3}$ Third, most employees in large-scale companies congregated and resided in the slums around their companies, which helped connect workers when they wanted to complain about living and working conditions, and aided them in collective bargaining. Finally, the activities of intellectuals, combined with the workers' protests, provided independent unions with sources of intelligence, for such areas as planning, organization and leadership. In particular, a great many college students revealed their compassion for, and anger towards, the miserable conditions of workers; they participated the workforce after graduating, and many of them became the leaders of confrontational trade unions.

\section{THE FEASIBILITY OF THE EXPANSION OF CORE EMPLOYMENT IN THE LABOR MARKET WITHOUT INDEPENDENT UNIONS}

So long as the issues of core employment, trade unions and labor markets can be carefully considered, we can possibly see a future of employment expansion and economic development without the necessity of independent trade unions in both Korea and China.

The decline of independent trade unions actually happened in Korea in the second half of the 1990s and the beginning of the millennium. Many scholars in Korea and abroad have presented various explanations about this phenomenon. Typical explanations argue that the "U-turn" of the domestic social situation caused the falling of the independent trade unions. One scenario explains this as the recovery of government "repression" policy toward the independent activities of workers. Another possible scenario suggests that the employers of most enterprises had begun to organize themselves in order to counterattack any rebellion by united workers. A third scenario is that this downturn in union influence came from internal contradictions and splits in the independent trade unions themselves. The fourth scenario

\footnotetext{
3 Around 20 per cent of people in South Korea believed in Christianity in the 1980 s, according to official Korean statistics.
} 
regards the middle class of Korea as beginning to "betray" the workers' independent union movement.

My opinion differs from these observations in several ways. First of all, government policy for dealing with labor conflicts became more neutral, fair and more convincing to workers. Workers then had more confidence in resorting to government ruling and arbitration in the face of labor conflicts, instead of resorting to confrontational actions. Second, the government changed their means of policy implementation from the heavy hand of the police force to educational and judicial processes. A rule of law helped to reduce long-lasting and unnecessary conflicts. Third, the government imposed a new policy of "no work no pay", on the basis of the civilian concept "no labor no food". The new policy decreased some unnecessary collective actions such as demonstrations and strikes, and brought, to some extent, a relative stability in production and in society, because workers then were forced to consider the higher induced costs when they participated in independent strike activities. Fourth, since the start of the 1990s an increasing number of Korean enterprises have begun to introduce modern HR management techniques from the U.S. and Japan, and have carried out a so-called "new management strategy". This strategy includes a "new personnel system" that seeks to: link job performance with wage levels and promotions of an employee; inculcates a "corporate culture movement" to raise a firm's internal cohesion by requiring training programs, by giving tours to employee relatives and offering entertainment events, leisure clubs and leisure travels; develops a "labor-union strategy" in order to rationally build up a good relationship with employees and with union members, and in turn cause employees to be more rational, friendly and lawful; and introduces a "flexible working time system" in companies that allows employees to have more choices in work time and contract styles and lets employers have greater flexibility in hiring across the range of part-time, temporary and foreign workers with lower labor and transaction costs. In conclusion, what has happened in Korea is that the traditional employment style, with its confrontational techniques and its discouragement of innovation, has been altered into the core employment style, incorporating cooperative techniques and active innovation.

In China and overseas, there were many scholars calling for the establishment of independent trade unions throughout the country. In some ways this argument seemed reasonable, especially when the miserable conditions of lower-level workers were borne in mind. However, consideration must be centered on the real purposes behind the establishment of independent trade unions and a thorough examination of alternative arrangements.

One purpose in considering appropriate employment arrangements in China ought to be the balance of employer and employees rights, which allows both parties to participate in entrepreneurial innovation and to share the fruits or results of productivity growth. Another purpose should be the balance of employee rights and government power, in which the legal rights of workers are to be protected by the government. and governmental power is to be effectively monitored and legally restrained by the workers.

What measures can be found to reach the necessary balance? Quite a few exploratory attempts concerning these kinds of balances in China have appeared. One attempt occurred in the area of enterprise management. Generally, high technology and large-scale enterprises in China have adopted new models of HR, the corporate culture and the idea of team production in business managerial operations. The relationship of the employer and employees tend to be better off without the interference of an independent trade union.

Another positive exploration has appeared in the reform of SOEs. Some old SOEs, like the Xinhua Bookstore Group, Ltd., in Wuhan, learned from the lesson of "mistakenly reducing employees to raise efficiency", which had seriously hurt innovative activity and company growth. Instead, they put into place a new measure of reform to "stabilize employees to raise efficiency". The new measure did not cause the lay-off of more employees, but effectively stimulated the efforts and innovatory activities of its marketing and operation employees. Thereafter production growth greatly improved in the Xinhua 
Bookstore Group by as much as 120 per cent annually.

The third important exploration was carried out in the traditional or official trade union system in China. An example of this system might be the situation where the chair of an official union in a firm holds a concurrent position as one of the directors of the board or the chair of the supervision board in a SOE that has been transformed into a corporation.

Other examples have been the enforcement of the vertical link between local unions and the headquarters of the all-China union in order to more effectively protect the legal rights of union members, and to allow the traditional trade unions to help employees in wider and more lasting ways, such as to helping employees in court whenever necessary.

Finally, another crucial attempt that should be mentioned is that the government has begun to pay increasing attention to the living and working conditions of the migrant and unskilled workers, especially those from rural areas. The government has helped migrant workers through reducing any barriers obstructing job searches, including the formalities of looking for work and the burden of taxation, and by giving subsidies in medicine, workplace injury care, labor market services and training.

\section{VI.CONCLUDING REMARKS}

From the experience and practice of South Korea and China, it is possible and feasible in a market economy to build up an efficient and equitable labor market without confrontational trade unions. The conditions to realize such a labor market in which a core employment system can develop and expand smoothly include the earnest efforts of the whole society - the government, the entrepreneurs and the working individuals of that society.

For the government of China or South Korea, the main effort will need to focus on the insistence on, and implementation of, the principles of a "rule of law". The government must purge the harmful tradition of the "rule of dictatorship" that resulted partly from the negative effects of Confucian culture and partly from the late modernization of the economy and society. By building up as properly as possible a system of legislation, administration and judicature in the society, the government can proceed in the right direction when pushing ahead with both efficiency and equity, imposing a stable and consistent policy of macroeconomic regulations on the national economy, and encouraging and protecting enterprise innovation and core employment development. Also, the government must establish the basic system of a social security network in the face of the changes in modern society and family structure. The government, especially in the case of China, should also place a high priority on the progress of economic reform in order to establish an all-round market economy, balance development between different groups of people and areas, reduce and eliminate the effects of the environmental pollution and resource waste on the natural environment, and maintain the ecological balance, health and working conditions. Collectively, these efforts will contribute to raising the hope for cooperation among workers who would otherwise resort to confrontational unions in desperation.

The main internal concern for business ought to be the idea of the "market economy as innovation" , or "speculation". An enterprise can only achieve sustainable competitiveness and success by the means of innovation, rather than by exploitation of employees, taking advantage of governmental policy gaps, or making money from illegal profits. Firms must prepare to implement a modern HR strategy and catch up with the international standards of SA8000 (for stake-holders) as well as the ISO9000 series (for product quality) and ISO14000 series (for environment protection) as early as possible to enhance their core competence and core employment. Finally, firms should have an open mind to requests proposed by employees and even trade unions, in order to create a cooperative atmosphere and establish a win-win situation. 
For the working individual, an effort needs to be made in promotion of individual knowledge and skills, keeping in mind their lawful rights and responsibilities as an employee, an investor, and a consumer. An employee also must be aware of the details of the labor laws and their related institutions, and keep an open mind to the information from community management and the enterprise itself. An employee should train in a specific skill area in order to take an efficient part in the division of labor and gain social respect, to be able to enjoy the processes of democratization and modernization of society, and to have well-rounded personal development while being able, irrespective of gender, to protect personal legal rights effectively.

\section{REFERENCES}

Bai, MooKi, 1982, "The Turning Point in the Korean Economy," Developing Economics 20. cited in H. Koo, 2004, p. 39.

Choi, Jang Jip, 1992, "Why is the Korean labor movement failing in political organization?," cited in H. Koo, 2004.

Ehrenberg, R. and Smith, R, 1997, Modern Labor Economics, New York, Addison-Wesley.

Freeman, R., 1979, Labor Economics, New Jersey, Prentice-Hall.

Koo, H., 2004, Korean Workers: The Culture and Politics of Class Formation, Beijing, Social Sciences Documentation Publishing House (Chinese edition).

Schumpeter, J., 1912, The Theory of Economic Development: An Inquiry into Profits, Capital, Credit, Interest, and the Business Cycle, 1934 ed., Harvard, Harvard University Press.

Song, Byung-Nak, 1994, The Rising of Korean Economy. Beijing, Commercial Press (Chinese edition).

Wang, Cheng, 2002, "A New Theory of Employment in China: Theoretical Analysis of Core Employment and Non-Core Employment”, Economic Research Journal 12, 79-87.

Wang, Cheng, 2003, “Income Distribution during Taiwan's Industrialization”, in Li and Pan (ed.), Taiwan in the Twenty-First Century, New York, University Press of America.

Wang, Cheng, 2004, "Life Cycle of China's Social Security System”, China and World Economy 12(4)(Jul-Aug), 46-57. 